IRA-International Journal of Management \& Social Sciences

ISSN 2455-2267; Vol.04, Issue 01 (2016)

Institute of Research Advances

http://research-advances.org/index.php/RAJMSS

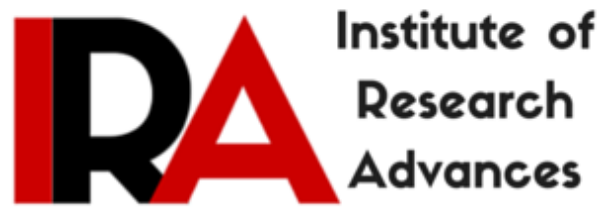

\title{
Socio-Religious and Political Changes in Punjab during the Second Half of Nineteenth Century
}

\section{Dr. Karanbir Singh}

Assistant Professor, Lyallpur Khalsa College, Jalandhar.

DOI: http://dx.doi.org/10.21013/jmss.v4.n1.p16

\section{How to cite this paper:}

Singh, K. (2016). Socio-Religious and Political Changes in Punjab during the Second

Half of Nineteenth Century. IRA-International Journal of Management \& Social Sciences (ISSN 2455-2267), 4(1). doi:http://dx.doi.org/10.21013/jmss.v4.n1.p16

(C) Institute of Research Advances

\section{(cc) EY-NC}

This works is licensed under a Creative Commons Attribution-Non Commercial 4.0 International License subject to proper citation to the publication source of the work.

Disclaimer: The scholarly papers as reviewed and published by the Institute of Research Advances (IRA) are the views and opinions of their respective authors and are not the views or opinions of the IRA. The IRA disclaims of any harm or loss caused due to the published content to any party. 


\section{ABSTRACT}

After the death of Maharaja Ranjit Singh, the East India Company defeated the Khalsa Army of Lahore Darbar in two Anglo-Sikh Wars. Being astute political masters, the British felt the lurking fear of simmering discontent among the Punjabis against their rule. For safeguarding the logistics of administration, efficacious precautionary measures were undertaken by them to satisfy the grievances of certain sections of the society so that British rule would face lesser political instability and enmity of the natives. After 1857, the British conducted a thorough study of ethnographic, fiscal, geographical, political, social and religious conditions of Punjab and oriented their administrative policies to suit the best interests of the Empire. Far-reaching political, economic and social changes were introduced by the British to strengthen their hold over all branches of administration. A new administrative hierarchy, composed of Anglo-Indian elements was firmly established and it embraced every activity of the state.

Key words: Political, Social, Religious change

Punjab was the last important province in India to be incorporated into the British Empire. After the death of Ranjit Singh on 27 June 1839, the East India Company defeated the Khalsa Army of Lahore Darbar in two Anglo-Sikh Wars. However, the annexation of Punjab on 29 March 1849 was not an easy task. The British suffered massive losses during the said wars and even after the capture of Lahore, sporadic military resistance by Sikh chiefs at isolated places created administrative troubles for some time. Geographically, at that time, Punjab was a big province. The present western Punjab and North-Western Frontier Province in Pakistan were parts of it. Haryana, Himachal Pradesh and Delhi were also parts of its geographical territory. Lieutenant-Governor of Punjab was the chief administrator of the province.

Less than a decade after Punjab's annexation, British masters faced the great revolt of 1857, which put them on their tenterhooks because they had to protect their most coveted Asian colony. In Punjab, the scale and extent of the revolt did not match the tempo of hostility against British which otherwise was widespread in north-central parts of India. This was because many of the Sikh princely rulers whole-heartedly supported the British with men and money. Timely military help, rendered by native Sikh rulers enabled the East India Company to easily put down the sporadic armed uprisings in different pockets of Punjab. British highly appreciated the valuable loyal services of the Punjabi royal families during this turmoil and publicly accepted their timely contribution. In less than ten years from the end of the Second Sikh War, the British and Punjabis together saved India from mutineers (1923, p. 25). However, being astute political masters, the British felt the lurking fear of simmering discontent among the Punjabis against their rule. For safeguarding the logistics of administration, efficacious precautionary measures were undertaken by them to satisfy the grievances of certain sections of the society so that British rule would face lesser political instability and enmity of the natives.

After 1857, the British conducted a thorough study of ethnographic, fiscal, geographical, political, social and religious conditions of Punjab and oriented their administrative policies to suit the best interests of the Empire. Politically, they attempted at effecting stability in the province with the passing of the Government of India Act, 1858. As per this Act, the government and revenue of India, including that of Punjab, were placed under the direct rule of the British Crown. Far-reaching political, economic and social changes were introduced by the British to strengthen their hold over all branches of administration. A new administrative hierarchy, composed of Anglo-Indian elements was firmly established and it embraced every activity of the state. Sohan Singh Josh has used the stereotype word "a prison house" for Punjab of this time because of the overarching reach of alien authorities in all spheres of the provincial life (Josh, 2007, p. 34). 
The newly acquired province witnessed reorganisation of its armed forces. The reappraisal of the situation made British administrators to completely abandon the old recruitment policy. Punjabi Muslims, Rajputs, Gurkhas, Dogras and especially the Jat Sikhs were preferably recruited in the armed forces. The colonial masters designated these communities as martial races who possessed hereditary traits of fighting skills. British recognised muscularity, fidelity, loyalty and bravery as inherent traits of these races. When the command of the Indian Army was placed under Lord Frederick Robert (1885-93) and Lord Horatio Herbert Kitchener (1902-09), the martial race theory gained a considerable official support and the composition of the army tilted towards Punjabis. Moreover, the scale of financial resources for building strong military infrastructure in Punjab was unmatched as compared to other provinces of colonial India. Sensing vulnerability of the province due to its close proximity to Central Asia, railways, roads and cantonment towns were established at strategic places. The strategic importance of the province could be gauged from this comment - It is interesting to note that when the century opened, of the ten divisions of the Indian Army, four were stationed in the Punjab (Malik, The History of the Punjab, 1799-1947, 1970, p. 227). Punjabis got the acclaimed epithet of "Sword Arm of the Raj" as martial culture of Punjab contributed immensely to enhance the manpower of the colonial armed forces. It was reasonably accepted in the British corridors of power that the Sikh race was the best martial material available to upkeep, shield and strengthen the Empire. With this belief, Punjab became the main recruiting centre for the military and "towards the end of nineteenth century, the region replaced the older areas of Bombay, Madras and Bengal as the major centre of recruitment for the Indian Army (Talbot, 1988, p. 38).

At the civil front, the quest to find political collaborators made British attempt to cultivate good relations with the native Sikh rulers, local chiefs and landlords. They distributed numerous land grants and leased out wastelands to those who had actively served the Empire during the revolt of 1857. This kind of political generosity was not a new phenomenon in the Punjabi society as erstwhile Mughal and Sikh rulers had also distributed land liberally to their cronies and military allies for securing their loyalty. The support rendered by these sections of society extended a helping hand to the British for maintaining law and order in the province. As for the case, "From the 1860s onwards, the British were constantly searching for allies amongst the region's rural population" (Talbot, 1988, p. 49). They hand-picked the erstwhile local powerful chiefs, who suffered a decline in the social state of things after the fall of the Sikh rule and used them for running the administrative affairs smoothly. In that political astuteness, "Gifts of squares of land and honours of distinction such as 'Sardar Bahadur' and 'Rai Bahadur' were bestowed on the chiefs, landlords and priests, as also honorary official positions of distinction like that of Honorary Magistrate, Zaildar, Nambardar etc" (Puri, Ghadar Movement: A Short History, 2011, p. 8). The big landlords began to regard the British rule as a kind of blessing for them. Zaildars, Lambardars held hereditary offices and these petty influential persons assisted government officials at the local levels as intelligence-cum-law and order agents. This process of social engineering led to the emergence of a new class of loyalists which unremittingly worked for the stability and continuance of the foreign rule. Due to its proximity to the alien establishment, the men of this class enjoyed a prestigious as well as pretentious position in the society. In diverse ways, these families were tied into the functioning of the imperialist rule and the rewards for this proved in the Punjab to be considerable (Ali, 1989, p. 75). (Puri, Ghadar Movement: A Short History, 2011)

This utilitarian approach of the British rule absorbed in itself a large number of vested partners in the imperial hierarchy at lower rungs. With the support of native chiefs, British authorities successfully demonstrated the grandeur of imperial paraphernalia and introduced the elements of fear, subservience and servility among the masses. It was widely propagated among the illiterate masses that the British Army was undefeatable and that the sun never sets in the British Empire. This kind of 
political entrenchment brought stability to the province and the imperial interests of the Pax Britannica influenced every activity of the provincial life.

The incorporation of Punjab into the whirlpool of imperialist market economy and the introduction of a new administrative network of officials, laws, regulations and courts here was a crucial development (Puri, Ghadar Movement: A Short History, 2011, p. 4). The imperialists colonised the agriculture and with this began the drain of agro-resources from Punjab. Imperialist market economy spread its web of vicious exploitative policies into the countryside. Historically, as a fact, "The period of its integration in the Empire roughly coincided with the period of Britain's transition to the epoch of imperialism and India's more rapid conversion into its agrarian and raw material appendage and a market for its commodities." (Singh P. , 1981, p. 20). The aim of the government was to develop Punjab as a cost-effective food basket for European consumption and a prosperous market for its finished articles, which was a usual practice in other parts of the country. Within a short span of half a century, the province saw revolutionary changes in the means of irrigation, communication and transportation. It considerably transformed the relationship between the economy and the land. Newly built railway networks connected the Punjab's agriculture with the national and international markets. Cultivation of cash crops such as wheat, cotton and sugarcane for export were preferred by colonial government to the crops for domestic consumption.

The object of the colonial state was not merely economic exploitation, but also safeguarding the political stability of the imperial regime. Keeping multifarious considerations of the political establishment in mind, from 1885 onwards, the British started the dual process of agricultural colonisation and canalisation in western Punjab. The authorities brought many families from central Punjab to develop the arid lands in this part of the province. Here, large tracts of land were reserved for ex-servicemen to compensate their loyal services to the Empire. Irrigation facilities increased agricultural output in these areas and enabled the land grantees to raise their economic status considerably. But with the passage of time, irrigation facilities and agricultural produce created an illusion of general prosperity as colonial state enhanced its revenue demand from peasants year after year.

For the British, an assured source of revenue was indispensable for maintaining the new administrative set-up including judicial, police, agricultural, revenue and canal irrigation. The main occupation of the Punjabis was agriculture. The regular land revenue extracted from agriculture incurred handsome income to the government and was "by far the most important source of income for the state" (Ali, 1989, p. 4). The share of revenue was to be paid at a fixed time in cash and was not negotiable under any circumstances. The government's method of collection of land revenue was rigid in its practice and remissions or concessions were hardly permissible to the affected peasants. The British put the onus of paying land revenue on the peasant, even if a natural calamity caused a crop failure. As a result, to meet basic consumption needs and government obligations, the middling strata of rural society tended to be drawn into the web of debt. For a person eking out his living from land, non-payment of revenue could cause loss of land ownership. This social stigma pushed him towards the flap of debt. And once a peasant fell into the debt trap, it was difficult for him to come out of the clutches of money lender.

For the Punjabi peasantry at large, imperial economic policies worked as a push factor to borrow money in the times of need. Anyway, the trend of money lending and borrowing was not new in the Punjabi society. Before the advent of the British, the peasants borrowed to meet varying degrees of the necessities of life, but after the annexation of the Punjab, they borrowed mostly for satiating the state demand for revenue and water tax. Cash loans to meet land revenue and water rate payments became essential when the proceeds of the harvest left no surplus after consumption requirements had been set aside or the moneylenders' obligations met (Mukherjee, 2005, p. 41). As small landowning 
class needed credit either because of the natural calamities such as famine, drought, epidemics, floods or sudden and sharp variations in prices, or purchasing plough animals or seed, they bore the sharpest brunt of the colonial British rule. In this way, fulfillment of the necessities of life became difficult for small and middle class landowning community. For them, "Symptoms of this economic distress were accentuated by the integration of Punjab with the colonial capitalist market economy." (Puri, The Ghadar Movement: A New Consciousness, 2000, p. 146).

In Punjab, market driven economy converted the land into a valuable asset in times of need and land rates increased significantly in the colonial period. The sale of land became more profitable than cultivation. The chief reason for increase in the income earning from agriculture was the increase in the price of land; it rose from a mere rupees 10 per acre in 1870 to more than rupees 100 per acre by the turn of the century (Calvert, 1922, p. 219). The peasant could mortgage land for immediate credit and borrowing became a necessity for subsistence in times of scarcity. The boom in land prices in Punjab simultaneously led to a rapid growth in agricultural indebtedness. For peasants, repayment of loans was not easy as income from agriculture often fell short of the anticipated expenditure on it.

In these circumstances, the viable option available to peasants was to get enrolled in the army or undertake journeys in search of employment. Migration from villages to towns, in other parts of the country or abroad could be made possible by securing a loan, often against a mortgage of land (Mukherjee, 2005, p. 43). There were ample reasons which forced the Punjabis to choose the path of migration. "They were compelled to leave their homes and go abroad because of three reasons - first, they were unable to pay the land revenue, and other direct and indirect taxes of the government; second, they wanted to earn enough money to pay off the debts of the usurer money lending classes that lay heavy on their backs; third, they were eager to improve their own backward economic condition of life (Josh, 2007, p. 51)."

To migrate, to a foreign land was not easy as it required a surety of a certain amount in the pocket of the immigrant, which simply could not be borne by everyone. Another option available for peasants to improve their lot was to get them recruited in the army. Many of them had readily joined the military service for an assured income at the end of the month. Economic necessities and opportunities were often fundamental push factors for most recruits seeking enlistment into the army (Yong, 2005, p. 79). A recruit in the army received rupees seven a month as salary and free travel on railways. Military service was considered by people as another avenue for employment and a regular pay at the end of the month at least set their home expenditure in a balanced state. These recruits, with an element of loyalty towards the British Crown, began to regard themselves as part of the privileged sections of the society. In fact, a soldier in uniform carried honour in the village community and was called Fauji Sahib. Military service accordingly became an exclusive opportunity that was guarded jealous by those who enjoyed that privilege (Yong, 2005, p. 83). British utilised the services of the Punjabi recruits in and outside India for fighting imperial wars. The number of Punjabis in the army rose by 309 per cent between 1858 and 1910 (Yong, 2005, p. 7).

Military service, of course, helped in substantiating the family income, but at the time of natural calamities even this belied the family's expectations. Famines repeatedly occurred in the Punjab during fifty years of the British rule. From 1860 to 1901, the province was hit hard five times by famines and serious droughts (Sohal, 1992, p. 76). The famine of 1869 coupled by heavy mortality of livestock accentuated the problem of indebtedness. Agriculturists did not have enough to pay the state demand of land revenue on time, and as such, they borrowed from moneylenders to manage their accounts. Thus, there ushered an era of Punjab's indebtedness which had never been known in the country before (Nijjar, 1974, p. 127). It was an irony of the colonial rule that while British exported large quantities of foodgrain from Punjab, the people within India were suffering from hunger and 
hardships. The export of foodgrain was not checked even during the famine years of 1896-97 and 1899-1900 (Puri, Ghadar Movement: A Short History, 2011, p. 6).

According to Malcolm Darling, "If it is true that debt follows credit, those who have no credit will have no debt (Darling, p. 211). He points out that massive canalisation in Punjab by the British caused a spurt in agricultural wealth, but prosperity caused a demoralising effect on the Punjab's peasants (Sohal, 1992, p. 75). He, however, excuses the British government for being responsible for indebtedness of the peasants and attached relative prosperity of peasants responsible for accruing debt. Besides, he regards Punjabi social customs, improvidence, illiteracy and astuteness of moneylenders were the real factors responsible for rural indebtedness.

In this scenario, the British felt the need to safeguard the interests of landowning agriculturalists on whom the political stability, revenue proceeds and military recruitment heavily depended. Taking all these matters into consideration and with an object to protect the agriculturists from the clutches of moneylenders, a paternalistic legislation, the Punjab Alienation of Land Act was passed by the Punjab government in 1901. This Act restricted the sale and purchase of agricultural land only to agricultural communities. It succeeded in safeguarding the interests of cultivators, but at the same time, it gave birth to a new class of landowning agricultural money lending class which provided credit to small and middle strata of the peasantry for meeting its day-to-day needs. This Act restricted the passing of agricultural land into the hands of moneylender but failed to solve effectively the crisis of rural indebtedness. The question as to who was an agriculturist was not decided by actual occupation but by caste. By that standard, the state recognised only Jats, Rajputs and members of Scheduled Castes as agriculturists. Other castes of Hindu and Muslim communities were largely left from the purview of this legislation. This compartmentalisation of the landowning class caused a silent grudge in the hearts of those who were denied their due by this Act. Also, later on, this Act sprang the fangs of communalism in the social fabric.

Punjab witnessed a series of social and religious reform movements which widely influenced the psyche of people. One of the important politico-religious developments after annexation was the birth of Namdhari or Kuka Movement. The movement was a call to return to the true credentials of the Sikhism as propounded by Guru Gobind Singh - the tenth Guru of the Sikhs. The founder of the Namdhari Movement, Baba Ram Singh was born in Bhaini Arayian (now called Bhaini Sahib) village of Ludhiana district in February 1816 (Ahluwalia, 1965, p. 40). In fact, the movement, in its political aspirations was a freedom movement-in-the-making. The Namdhari Movement which embodied to an extent the anti-feudal aspirations of the rural poor and the artisans and acquired anti-British character as it expanded, embodied the widespread spirit of non-acceptance of the British Raj by sections of the Punjabi population and in form became one of the earliest and embryonic indications of noncooperation (Singh P. , 1981, p. 15). Baba Ram Singh drilled his followers with stout sticks and trained them in warfare. In 1872, Namdhari Movement surfaced with full-grown militancy and posed a difficult challenge to the alien authorities. In his religious gatherings, Baba Ram Singh spoke of the wickedness of native Sikh rulers and their crony landlords; practice of idolatry and casteism in Sikhs and pretentious practices adopted by the Sikh priests in the Sikh gurdwaras and shrines.

Although, Baba Ram Singh was a non-believer in the Hindu beliefs and practices, he became an ardent protector of the cow - the sacred animal of the Hindus. Collision of the Namdharis with the British authorities came as a result of their attempt to stop the slaughter of kine (Singh K., 2004, p. 131). After a skirmish with Muslim butchers in Malerkotla, the Deputy Commissioner of Ludhiana, L. Cowan blew up sixty-six Namdharis by tying them to the mouths of cannons. Following this, British arrested Baba Ram Singh from Namdhari headquarters at Bhaini Sahib and deported him to Burma in 1885. At the same time, most of the Sikhs also feared the revolutionary character of the Namdhari Movement. Later on, owing to the liberal recruitment of the Sikhs in the British army, 
support of the Sikh elite to the British and strict vigil on Namdharis' movements by the authorities, the movement gradually restricted itself to the religious activities only.

At the same time, Arya Samaj was making inroads into the Punjab. Within a short span of time, Arya Samaj made its presence felt in the Punjab. The Samaj, founded by Swami Dayananda Saraswati in 1875 at Bombay, got a ready response in Punjab. In 1877, Dayananda opened a branch of the Arya Samaj at Lahore. After Uttar Pradesh, Punjab had the highest branches of Arya Samaj during his lifetime. Lala Lajpat Rai and Ajit Singh, who led the agrarian agitation of 1907, were the prominent Arya Samajists. Hindus and Sikhs of the province warmly welcomed his call 'Back to Vedas' which stressed on the purity of original religion and rejected all false beliefs and practices prevalent in Hinduism. In fact, Arya Samaj was a reform movement based on rationality. Shudhhi, a ceremony of purification, was an important hallmark of the movement, seeking readmission of the defectionists back into the Hindu faith. Proselytisation became an important part of the Samaj's activities. With this ceremony a spirit of militancy entered into the pantheon and it directly confronted the Muslim, Christian as well as the Sikh missionaries. Later on, this practice of conversion gave stimulus to Hindu-Muslim-Sikh strife in the society. The process of identity reformation paved the way for communalism to make its headway in the body politic of the Punjab. In fact, "Loyalty to a set of ideals and to the group that possessed those ideals heightened existing social divisions, setting one group against all other" (Jones, 1989, p. 314).

Another socio-religious reform movement in Punjab, the Singh Sabha was trying to purge Sikhism of false beliefs and practices that had crept in with the passage of time in the Sikh religion. The movement emphasised on restoring the pristine purity of the Sikhism. In 1888, prominent members of the Sabha, Gurmukh Singh, Jawahar Singh and Ditt Singh initiated reform process and established a Khalsa Diwan in Lahore. The Singh Sabha created a sense of cultural awareness as well as identification, thereby furnishing a base for future progress (Singh F. , 1972, p. XVII). The Sabha published historical and religious books to propagate the knowledge of the teachings of the Sikh Gurus. Ditt Singh issued Khalsa newspaper and emphasised on the distinct identity of the Sikhs. He wrote many books and pamphlets on the Sikh history, theology and polemics. Ditt Singh died at a young age in 1901. With his death, Khalsa Diwan Lahore became redundant. In 1903, another faction of the Sikhs formed Chief Khalsa Diwan in Amritsar. Diwan was an apolitical entity which stood for nurturing good relations with the British. English educated elite members of the Sabha tried their efforts to cultivate loyalty to the Crown (Singh K. , 2004, p. 142). (Malik, Muslim Anjumans and Communitarian Consciousness, 2000) The British helped Diwan leaders to establish educational institutions. Also, the colonial authorities used them to upkeep Sikh shrines. Untill the Gurdwara Sudhar Lehar (Sikh Reform Movement) was launched in 1920s, when new grassroots leadership took a firm stand for community rights, the British continued to extend support and favour to Singh Sabha leaders.

The decade, 1880-1890 saw the birth of several Muslim associations (Anjumans). These associations, like other religious communities aimed at the religious, material and social uplift of community members. At the same time, they faced a grave threat from the increasing proselytising activities of the Christian missionary societies and growing economic prosperity of the Hindus, who, by virtue of their advancement in education, commerce and public services, were emerging as a dominant community in the province (Malik, Muslim Anjumans and Communitarian Consciousness, 2000, p. 112). Thus, the emergence of these Anjumans represented a new consciousness and responsiveness among the Muslims. Anjuman-i-Islamia, Lahore; Anjuman-i-Islamia, Amritsar; Anjuman-i-Himayati-Islam, Amritsar were some important associations which played an active role in the Muslim affairs. The objectives of these Anjumans were to propagate Islam, to appoint preachers, to publish pamphlets and journals and to make arrangements for the religious instruction of the Muslim boys and girls so as to ward off adverse affects of the teaching of other religions. The members of these 
associations strived for social reform and moral improvement of the Muslim community. They established several schools, orphanage homes and publishing houses. However, the membership of these Anjumans, except a few, was not large enough; it usually was confined to the range of 100-400. Members of the middle and upper middle classes such as scions of aristocratic families, honorary magistrates, lawyers, traders and government officials assumed the leadership of these Anjumans. These Anjumans contributed significantly in the field of education. The Muslim community set up schools (Madrassas) for girls and boys in Batala, Ludhiana, Jalandhar, Shimla, Ropar, Amritsar, Rawalpindi and Multan. Although, the education imparted in these institutions was not of incredibly high standard, but they fulfilled the great need of the Muslim community. Community leaders placed special emphasis on religious and moral education. All Anjumans stood for the Muslim unity and organised a stiff resistance to the activities of the Hindu revivalist and Christian missionary societies. British policies also stimulated their assumption of communal overtones and politics. Despite their political and religious rigidity, these Anjumans played an important role in the history of the Punjab, especially in the field of the Muslim education and social reform.

\section{References:}

Ahluwalia, M. (1965). Kukas: The Freedom Fighters of the Punjab. Bombay: Allied Publishers.

Ali, I. (1989). Punjab under Imperialism, 1885-1947. New Delhi: Oxford University Press.

Calvert, H. (1922). Wealth and Welfare of the Punjab. Lahore: Govt. Press.

Darling, M. The Panjab Peasant in Prosperity and Debt. 1947: Oxford University Press.

Jones, K. W. (1989). Arya Dharam: Hindu Consciousness in 19th Century Punjab. New Delhi: Manohar Publications.

Josh, S. S. (2007). Hindustan Gadar Party: A Short History. Jalandhar: Desh Bhagat Yadgar Committee.

Malik, I. A. (2000). Muslim Anjumans and Communitarian Consciousness. In I. B. (ed.), Five Punjabi Centuries: Polity, Economy, Society and Culture 1500-1990. New Delhi : Manohar Publications.

Malik, I. A. (1970). The History of the Punjab, 1799-1947. Delhi: Neeraj Publishing House.

Mukherjee, M. (2005). Colonializing Agriculture: The Myth of Punjab Exceptionalism. New Delhi: Sage Publications.

Nijjar, B. S. (1974). Panjab Under the British Rule (1849-1902),Vol. I. New Delhi: K.B. Publications. (1923). Punjab Administrative Report, 1921-22, Vol. I,. Lahore: Government of Punjab.

Puri, H. K. (2011). Ghadar Movement: A Short History. New Delhi: National Book Trust.

Puri, H. K. (2000). The Ghadar Movement: A New Consciousness. In H. K. Puri, \& P. S. Judge, Social and Political Movements: Readings on Punjab. Jaipur: Rawat Publications.

Singh, F. (1972). Who's Who: Punjab Freedom Fighters, Volume I. Patiala: Department of Punjab Historical Studies, Panjabi University.

Singh, K. (2004). A History of the Sikhs 1839-2004, Vol. 2. New Delh: Oxford University Press.

Singh, P. (1981). The Rise of the National-Liberation Movement in the Punjab from 1905 to 1914 (Unpublished Ph.D. Thesis). Moscow: The Institute of Oriental Studies.

Sohal, S. S. (1992). A Note on Rural Indebtedness in the Punjab (1849-1947). Punjab History Conference Proceedings, Twenty-Fifth Session, Part I. Patiala: Department of Punjab Historical Studies, Punjabi University.

Talbot, I. (1988). Punjab and the Raj 1849-1947. New Delhi: Manohar Publications.

Yong, T. T. (2005). The Garrison State: The Military, Government and Society in Colonial Punjab, 1849-1947. New Delhi: Sage Publications. 